Does the Balassa-Samuelson theory explain the link between relative population growth and purchasing power parity?

A.F. M. Kamrul Hassan

School of Management and Governance

Murdoch University, 90, South Street, Perth, WA 6150

and

Ruhul Salim*

School of Economics \& Finance

Curtin Business School

e-mails: Ruhul.Salim@cbs.curtin.edu.au

and afmkamrulru@yahoo.com 
Does the Balassa-Samuelson theory explain the link between relative population growth and purchasing power parity?

\begin{abstract}
Relative population growth affects relative prices through the so-called BalassaSamuelson (BS) mechanism and that in turn impacts PPP. This paper empirically investigates the relationship between PPP exchange rate and relative population growth in a panel of 80 selected countries. Following the Balassa-Samuelson hypothesis this paper argues that relative population growth affects nominal wages that impact price levels and thereby impacts PPP. Using panel cointegration and fully modified ordinary least square (FMOLS) the empirical results show that there is stable relationship between PPP exchange rate and relative population growth in the long run. These empirical findings suggest that population growth have an important role in exchange rate determination through PPP.
\end{abstract}

Keywords: Balassa-Samuelson hypothesis; Purchasing power parity; population growth; panel cointegration

JEL Classification: F31, F29, C23 


\title{
Does the Balassa-Samuelson theory explain the link between relative population growth and purchasing power parity?
}

\author{
"Under the skin of any international economist lies a deep-seated belief in \\ some variant of the PPP theory of the exchange rate" \\ -Dornbusch and Krugman (1976; p.540)
}

\section{Introduction}

The purchasing power parity (PPP) exchange rate states that exchange rates between currencies are in equilibrium when their purchasing power is the same in each of the two countries implying that the exchange rate between two countries should equal the ratio of the two countries' price level of a fixed basket of goods and services. Since the introduction of the PPP theory, a large number studies either examine the validity of this theory or identify several factors of systematic divergence of the PPP from the equilibrium exchange rate (Frenkel, 1978; Krugman, 1986; Dornbusch, 1987; Taylor, 1988; Mark, 1990; Betts and Devereux, 1996; Wu, 1996; Sarno and Taylor, 2002; Wu and Chen, 2008 and Kalyoncu and Kalyoncu, 2008 to cite a few). The BalassaSamuelson (BS) mechanism ${ }^{1}$ has been considered as one of the leading explanations of real exchange rate departures from PPP. A large number of recent studies provided empirical evidence in order to support the Balassa-Samuelson hypothesis (BahmaniOskooee, 1992; Drine and Rault, 2003; Bahmani-Oskooee and Miteza, 2004; Genius and Tzouvelekas, 2008; and Lothian and Taylor, 2008 among others). The aim of this paper is not to test the Balassa-Samuelson hypothesis; rather it aims to examine whether there is a link between PPP exchange rate and the relative population growth in the spirit of the Balassa-Samuelson mechanism.

This issue of population growth, particularly the growth of the working age population is important and has received considerable attention in the popular press concerning its potential impacts on the economy. However, academic exercises combining relative population growth and PPP exchange rate are only a few. Aloy and Gente (2005) and

\footnotetext{
${ }^{1}$ Balassa and Samuelson independently argued productivity differentials as one of the most important long-run factors behind such divergence in their 1964 celebrated papers. Prior to Balassa and Sumelson Ricardo (1817) was the first and subsequently Harrod (1933) analyzed the factors behind the systematic divergence of national price levels. Ricardo asserts that domestic goods would be more expensive in 'countries where manufactures flourish' while Harrod emphasizes the existence of tradable and nontradable goods. Subsequently, Balassa-Samuelson proposition is referred to as the Harrod-BalassaSamuelson productivity differential hypothesis in the literature (Sarno and Taylor, 2002).
} 
Andersson and Österholm (2005) investigate that population structure affects real exchange rate through its impact on saving as postulated in the life-cycle hypothesis. Aloy and Gente use the overlapping generation model while Andersson and Österholm estimate the reduced form single equation in order to test their hypotheses empirically. However, this paper argues that relative population growth affects price levels through its effect on nominal wages and thereby impacts PPP. According to the BS mechanism labor is immobile across countries, so wage adjustments in response to increase (decrease) in working-age population in the traded relative to the non-traded good sector increase (decrease) the relative price of non-traded goods. This tends to appreciate (depreciate) real exchange rate. More closely related to the present paper, Salim and Hassan (2009) shows that relative population growth may affect long-run PPP through its effect on money demand and price levels. However, the theoretical model underlying this analysis is informal and untenable. Transaction demand for money model for demographic dynamics to affect the real economy is simply ad hoc. Not only that their results might be unreliable as these authors over looked crosssectional dependence in their panel data analysis. Therefore, the issue is formally analyzed in this paper in the light of the BS hypothesis. This paper uses data from 80 countries over 55 years to examine the link between relative population growth and PPP exchange rate.

The rest of the paper is organized as follows. The next section develops an analytical framework followed by the econometric methodology in section 3. Section 4 checks the validity of the relationship between PPP exchange rate and relative population growth by investigating the time series properties of the data and establishing the cointegration relationship between these variables. Concluding remarks and policy implications are given in final section.

\section{Analytical Framework}

There are mainly two variants of PPP theory: absolute and relative PPP. In its absolute form PPP states that the exchange rate between two countries' currencies equalizes the relative price levels of these economies, provided that the effects of trade barriers and transaction costs are negligible, i.e. $E=\frac{P^{h}}{P^{f}}$ (where $E, P^{h}$ and $P^{f}$ stand for exchange rate between the two countries' currencies, home price and foreign price levels respectively). However, absolute PPP theory is not a useful operational hypothesis, 
because information on national price levels are available in the form of price indices, but not on absolute price levels. For this complexity most of the empirical literature on PPP has focused on the relative PPP hypothesis. The relative version of PPP theory states that the exchange rate should have constant proportionate relationship to the ratio of national price levels, i.e. $E=k \frac{P^{h}}{P^{f}}$ (where $k$ is a constant). This implies that if home price level is higher relative to the foreign price level then PPP exchange rate will depreciate and vice-versa. In order to relate the relative population growth to PPP exchange rate, it is assumed that labor supply is directly proportional to population growth. It is also assumed that the home and foreign economy produce two types of composite goods: traded and non-traded and in each country aggregate price index, $P$ is the sum of weighted average prices of these two types of goods as follows:

$$
P=\eta P_{T}+(1-\eta) P_{N}
$$

where $\eta$ is the share of traded goods in the price index. Prices of traded and non-traded goods are determined by prices of labor and capital employed in those sectors. To examine how these prices relate to population growth we partially resort to BalassaSamuelson hypothesis as discussed in Gregorio et al. (1994) and Sarno and Taylor (2000). Production functions for traded and non-traded sector are given by the following Equations:

$$
Y_{T}=\theta_{T} L_{T}^{\alpha^{T}} K_{T}^{\left(1-\alpha^{T}\right)}
$$

and

$$
Y_{N}=\theta_{N} L_{N}^{\alpha^{N}} K_{N}^{\left(1-\alpha^{N}\right)}
$$

where $T$ and $N$ denote traded and non-traded goods, and $\alpha$ and $(1-\alpha)$ denote contribution of labor $(L)$ and capital $(K)$ respectively in the production process. Finally, $\theta$ is a productivity parameter. The model assumes perfect factor mobility and perfect competition in both traded and non-traded sectors. World (and hence domestic) interest rate $(\mathrm{R})$ and wages $(\mathrm{W})$ in two sectors are equal to their marginal products as follows, $W_{T}=\frac{\delta Y_{T}}{\delta L_{T}}, R_{T}=\frac{\delta Y_{T}}{\delta K_{T}}, W_{N}=\frac{\delta Y_{N}}{\delta L_{N}}, R_{N}=\frac{\delta Y_{N}}{\delta K_{N}}$. Perfect competition and perfect capital mobility imply $W_{T}=W_{N}=W$ and $R_{T}=R_{N}=R$.

Gregorio et al. (1994) show that under perfect competition prices in traded and nontraded sectors are derived by duality as follows: 


$$
P_{T}=\frac{1}{\theta_{T}} W^{\alpha^{T}} R^{\left(1-\alpha^{T}\right)} \alpha_{T}^{-\alpha^{T}}\left(1-\alpha_{T}\right)^{-\left(1-\alpha^{T}\right)}
$$

and

$$
P_{N}=\frac{1}{\theta_{N}} W^{\alpha^{N}} R^{\left(1-\alpha^{N}\right)} \alpha_{N}^{-\alpha^{N}}\left(1-\alpha_{N}\right)^{-\left(1-\alpha^{N}\right)}
$$

Equations (4) and (5) indicate that any change in wage $(W)$ or rate of return on capital $(R)$ changes prices of traded and non-traded sectors. Assuming a given $R$ the focus of this study is on $W$, which is determined in the labor market by demand and supply of labor.

Demand for labor comes from the firms involved in the production process. Supply of labor comes from the fraction of the total population that is at working age stage. Labor demand and supply functions can be expressed as follows:

$$
\begin{array}{ll}
\text { Demand function : } & L^{D}=L^{D}(w, \mathbf{x}) \\
\text { Supply function: } & L^{S}=L^{S}(w, \mathbf{y})
\end{array}
$$

where, $w$ stands for real wage and $\mathbf{x}$ and $\mathbf{y}$ include exogenous factors. Labor demand is a decreasing function while the supply is an increasing function of real wage. Any changes in exogenous factors will shift demand or supply schedules and change equilibrium wage. Exogenous variables those affect supply schedule include real unemployment benefit, tax rate (fraction of wage) paid by employee, size of working age population (Minford, 1983), unearned income, population between the ages 16 and 64 (Sarantis, 1981) and so on. Thus one of the obvious exogenous factors that shift the supply schedule is the size of labor force. Assuming a positive proportionate relationship between total population and working age people, a higher population growth (since labor is not mobile internationally according to the BS hypothesis) will increase the supply of labor, lower the equilibrium wage and thereby lower home price level relative to the world (Equation 1). Thus an increase in relative population growth results in depreciated real exchange rate. In a similar fashion, Obstfeld and Rogoff (1996) also argue that a rise (fall) in the relative foreign labor supply results in a rise (fall) in relative real wage at home. If this is the case then higher (lower) relative population growth at home will cause appreciated (depreciated) PPP exchange rate.

Hence, a negative relationship is hypothesized between PPP exchange rate and relative population growth rate based on the above discussion. Empirical data on PPP exchange rate and relative population growth rate may support this hypothesized relationship consistent with the BS effect through wage rates. Table 1 reports simple correlation 
coefficients between relative population growth and PPP exchange rate for 80 countries. Population growth rate is relative to the USA and PPP exchange rate is in terms of the USA dollar.

Table 1: Correlation between PPP and Relative Population Growth

\begin{tabular}{|c|c|c|c|c|c|}
\hline Country & Correlation & Country & Correlation & Country & Correlation \\
\hline Algeria & $\begin{array}{l}-0.891 \\
(0.000)\end{array}$ & France & $\begin{array}{l}-0.294 \\
(0.163)\end{array}$ & Namibia & $\begin{array}{l}-0.589 \\
(0.002)\end{array}$ \\
\hline Australia & $\begin{array}{c}-0.378 \\
(0.068)\end{array}$ & Gabon & $\begin{array}{l}-0.359 \\
(0.085)\end{array}$ & Nepal & $\begin{array}{c}-0.702 \\
(0.000)\end{array}$ \\
\hline Austria & $\begin{array}{l}-0.106 \\
(0.622)\end{array}$ & Gambia, The & $\begin{array}{l}-0.323 \\
(0.124)\end{array}$ & Netherlands & $\begin{array}{l}-0.162 \\
(0.449)\end{array}$ \\
\hline Bahamas & $\begin{array}{l}-0.828 \\
(0.000)\end{array}$ & Germany & $\begin{array}{l}\mathbf{0 . 0 3 9} \\
(0.855)\end{array}$ & New Zealand & $\begin{array}{l}0.176 \\
(0.410)\end{array}$ \\
\hline Bangladesh & $\begin{array}{l}-0.776 \\
(0.000)\end{array}$ & Guatemala & $\begin{array}{l}-0.503 \\
(0.012)\end{array}$ & Nigeria & $\begin{array}{l}-0.488 \\
(0.015)\end{array}$ \\
\hline Barbados & $\begin{array}{l}-0.646 \\
(0.001)\end{array}$ & Honduras & $\begin{array}{l}-0.762 \\
(0.000)\end{array}$ & Pakistan & $\begin{array}{l}-0.611 \\
(0.002)\end{array}$ \\
\hline Belgium & $\begin{array}{l}-0.505 \\
(0.012)\end{array}$ & Hong Kong & $\begin{array}{c}-0.170 \\
(0.427)\end{array}$ & $\begin{array}{l}\text { Papua New } \\
\text { Guinea }\end{array}$ & $\begin{array}{r}-0.415 \\
(0.044)\end{array}$ \\
\hline Bermuda & $\begin{array}{l}-0.440 \\
(0.031)\end{array}$ & Hungary & $\begin{array}{l}\mathbf{0 . 0 9 2} \\
(0.668)\end{array}$ & Philippines & $\begin{array}{l}-0.744 \\
(0.000)\end{array}$ \\
\hline Botswana & $\begin{array}{l}-0.945 \\
(0.000)\end{array}$ & Iceland & $\begin{array}{l}-0.440 \\
(0.031)\end{array}$ & Portugal & $\begin{array}{l}-0.580 \\
(0.003)\end{array}$ \\
\hline Burundi & $\begin{array}{l}-0.320 \\
(0.127)\end{array}$ & India & $\begin{array}{l}-0.839 \\
(0.000)\end{array}$ & Senegal & $\begin{array}{l}-0.405 \\
(0.050)\end{array}$ \\
\hline Cambodia & $\begin{array}{l}-0.650 \\
(0.001)\end{array}$ & Israel & $\begin{array}{l}\mathbf{0 . 1 2 6} \\
(0.558)\end{array}$ & Singapore & $\begin{array}{l}0.537 \\
(0.007)\end{array}$ \\
\hline Canada & $\begin{array}{l}-0.128 \\
(0.552)\end{array}$ & Jamaica & $\begin{array}{l}-0.514 \\
(0.010)\end{array}$ & Solomon Islands & $\begin{array}{l}-0.706 \\
(0.000)\end{array}$ \\
\hline $\begin{array}{l}\text { Central African } \\
\text { Republic }\end{array}$ & $\begin{array}{l}-0.732 \\
(0.000)\end{array}$ & Japan & $\begin{array}{l}\mathbf{0 . 8 9 2} \\
(0.000)\end{array}$ & South Africa & $\begin{array}{l}-0.762 \\
(0.000)\end{array}$ \\
\hline Chile & $\begin{array}{l}-0.847 \\
(0.000)\end{array}$ & Jordan & $\begin{array}{l}-0.537 \\
(0.007)\end{array}$ & Spain & $\begin{array}{l}-0.813 \\
(0.000)\end{array}$ \\
\hline China & $\begin{array}{l}-0.862 \\
(0.000)\end{array}$ & Kenya & $\begin{array}{l}-0.727 \\
(0.000)\end{array}$ & Sri Lanka & $\begin{array}{l}-0.405 \\
(0.050)\end{array}$ \\
\hline Colombia & $\begin{array}{l}-0.754 \\
(0.000)\end{array}$ & Korea, Republic of & $\begin{array}{l}-0.783 \\
(0.000)\end{array}$ & St. Lucia & $\begin{array}{l}-0.587 \\
(0.003)\end{array}$ \\
\hline $\begin{array}{l}\text { Congo, } \\
\text { Republic of }\end{array}$ & $\begin{array}{l}-0.312 \\
(0.137)\end{array}$ & Lesotho & $\begin{array}{l}-0.771 \\
(0.000)\end{array}$ & Swaziland & $\begin{array}{l}-0.800 \\
(0.000)\end{array}$ \\
\hline Costa Rica & $\begin{array}{l}-0.70 \\
(0.000)\end{array}$ & Luxembourg & $\begin{array}{l}-0.235 \\
(0.270)\end{array}$ & Sweden & $\begin{array}{l}0.229 \\
(0.281)\end{array}$ \\
\hline Cote d'Ivoire & $\begin{array}{l}-0.384 \\
(0.064)\end{array}$ & Macao & $\begin{array}{l}-0.716 \\
(0.000)\end{array}$ & Switzerland & $\begin{array}{l}-0.258 \\
(0.224)\end{array}$ \\
\hline Cuba & $\begin{array}{l}-0.446 \\
(0.029)\end{array}$ & Malawi & $\begin{array}{l}-0.229 \\
(0.282)\end{array}$ & Syria & $\begin{array}{l}-0.880 \\
(0.000)\end{array}$ \\
\hline Denmark & $\begin{array}{l}\mathbf{0 . 2 6 4} \\
(0.212)\end{array}$ & Malaysia & $\begin{array}{l}-0.604 \\
(0.002)\end{array}$ & Tanzania & $\begin{array}{l}-0.825 \\
(0.000)\end{array}$ \\
\hline $\begin{array}{l}\text { Dominican } \\
\text { Republic }\end{array}$ & $\begin{array}{l}-0.077 \\
(0.721)\end{array}$ & Maldives & $\begin{array}{l}-0.887 \\
(0.000)\end{array}$ & Thailand & $\begin{array}{l}-0.810 \\
(0.000)\end{array}$ \\
\hline Ecuador & $\begin{array}{l}\mathbf{0 . 0 8 3} \\
(0.700)\end{array}$ & Malta & $\begin{array}{l}-0.274 \\
(0.196)\end{array}$ & $\begin{array}{l}\text { Trinidad } \\
\text { \&Tobago }\end{array}$ & $\begin{array}{c}-0.801 \\
(0.000)\end{array}$ \\
\hline Egypt & $\begin{array}{l}-0.814 \\
(0.000)\end{array}$ & Mauritius & $\begin{array}{l}-0.205 \\
(0.335)\end{array}$ & Tunisia & $\begin{array}{l}-0.879 \\
(0.000)\end{array}$ \\
\hline $\begin{array}{l}\text { Equatorial } \\
\text { Guinea }\end{array}$ & $\begin{array}{l}-0.492 \\
(0.015)\end{array}$ & Mexico & $\begin{array}{l}-0.887 \\
(0.000)\end{array}$ & $\boldsymbol{U} \boldsymbol{K}$ & $\begin{array}{l}\mathbf{0 . 0 9 5} \\
(0.658)\end{array}$ \\
\hline Fiji & $\begin{array}{c}-0.508 \\
(0.011)\end{array}$ & Mongolia & $\begin{array}{c}-0.732 \\
(0.000)\end{array}$ & Vanuatu & $\begin{array}{c}-0.456 \\
(0.025)\end{array}$ \\
\hline Finland & $\begin{array}{l}\mathbf{0 . 3 9 7} \\
(0.055)\end{array}$ & Morocco & $\begin{array}{c}-0.893 \\
(0.000)\end{array}$ & & \\
\hline
\end{tabular}

Note: Figures in parentheses are $p$ values. 
The above Table clearly shows that there is significant negative correlation between relative population growth and PPP exchange rate in all countries except Denmark, Ecuador, Finland, Germany, Hungary, Israel, Japan, New Zealand, Singapore, Sweden and United Kingdom. However, the positive correlation coefficients of none of these countries are statistically significant except Japan. Moreover, simple correlation coefficients cannot be used to draw meaningful conclusions about the long run relationship between these two variables. Thus, this article starts with the examination of time series properties of these variables followed by cointegration relationship between them.

\section{Econometric issues}

The econometric issues involve the examination of the underlying data for stationarity and cointegrating relationship between variables. This section covers the issues related to unit root test and cointegration in panel data set.

Panel unit root test: The motivation to employ panel unit root test comes from the low power of univariate unit root tests like ADF or PP tests. Panel unit root tests are more powerful because of increased sample size. The alternative way to get large sample is to use long time series data, but this may cause the problem of structural break (Maddala and Kim, 1998). By using panel data set one can exploit the extra information contained in pooled cross-section time series data. Besides, the asymptotic distribution of panel unit root test is standard normal which is in contrast to univariate time series unit root tests that have non-standard asymptotic distribution (Baltagi at el., 2007). Several methods have been proposed to test stationarity in panel data among which three methods are widely used: Im, Pesaran and Shin (2003) [hereafter IPS], Levin, Lin and Chu (2002) [hereafter LLC] and Maddala and Wu (1999) [hereafter MW]. All these tests have their own limitations, such as LLC is applicable for homogeneous panel, where the autoregressive (AR) coefficients for unit roots are assumed to be the same across cross-sections. Although IPS allows heterogeneous panels, a major criticism of both LLC and IPS tests is that they both require cross-sectional independence. To see whether LLC and IPS can be used for the data under consideration Pesaran's (2004) CD test is done and it is found that the test statistic is 28.592 with $p$ value 0.000 , which implies that the null hypothesis of no cross-sectional dependence is strongly rejected. Therefore, these two tests are not applicable for the data set in hand. Although MW test also requires cross-sectional independence, Maddala and Wu (1999) find that MW test 
is more robust than LLC and IPS tests to the violation of this assumption. Moreover, they find that in a variety of situations the MW test is more powerful than IPS test, which, in turn, is more powerful than the LLC test. From these points of view, it appears that MW test, also called Fisher's test, is suitable for the panel data under consideration.

Panel unit root tests are similar although not identical to unit root tests conducted on a univariate time series. Consider an AR(1) process for panel data as follows:

$$
y_{i, t}=\rho_{i} y_{i, t-1}+X_{i, t} \delta_{i}+\varepsilon_{i, t}
$$

where, $i=1,2, \ldots, N$ represents cross-section units that are observed over periods $t=1,2, \ldots, T . X_{i, t}$ represents the exogenous variables including any fixed or individual trend, $\rho_{i}$ is the autoregressive coefficient and $\varepsilon_{i, t}$ is idiosyncratic disturbance. If $\left|\rho_{i}\right|<1$, $y_{i}$ is said to be weakly stationary and if $\left|\rho_{i}\right|=1$, then $y_{i}$ is said to contain a unit root. There are two assumptions that are made in different tests about $\rho_{i}$. LLC test assumes that the persistence parameter $\rho_{i}$ is common across cross-sections so that $\rho_{i}=\rho$ for all $i$. However, in IPS and MW test $\rho_{i}$ is allowed to vary freely across cross-section, which seems more reasonable. Moreover, as IPS is designed for balance panel this study concentrates on MW test only. Consider the ADF regression for each cross-section unit as follows:

$$
\Delta y_{i, t}=\rho_{i} y_{i, t-1}+\sum \beta_{i, t} \Delta y_{i, t-j}+X_{i, t} \delta+\varepsilon_{i, t}
$$

The null hypothesis is $H_{0}: \rho_{i}=0$ for all $i$ and the alternative is

$$
H_{1}: \begin{cases}\rho_{i}=0 & \text { for } i=1,2, \ldots, N \\ \rho_{i}<0 & \text { for } i=N+1, N+2, \ldots, N\end{cases}
$$

MW uses Fisher's (1932) result to derive tests that combine the $p$-values from the individual unit root in each cross-sectional unit. If the $p$-value from individual unit root test for cross-section $i$ is defined as $\pi_{i}$, then under the null hypothesis of unit root for all $N$ cross-sections, the test statistic is given by $-2 \sum_{i=1}^{N} \log \left(\pi_{i}\right) \rightarrow \chi_{2 N}^{2}$. Banerjee (199) notes that MW test is a non-parametric, and may be computed for any arbitrary choice of a test for the unit root. 
Panel cointegration: Estimation of long run equilibrium relationship occupies a significant share in empirical time series econometrics. Long run relation among multiple time series of a single cross-section unit is investigated using cointegration technique developed by Engle and Granger (1987), Johansen and Juselius (1990), Johansen (1991, 1995) and Phillips (1991). The counterpart of this type of cointegration test is panel cointegration. In the literature residual-based approach and system approach have been suggested for testing cointegration in panel data set. Two widely used residual-based panel cointegration tests are those of suggested by Pedroni (1999, 2004) and Kao (1999) and the system approach is suggested by Larsson et al. (2001). However, Monte Carlo comparison by Gutierrez (2003) shows that in homogeneous panels Kao's (1999) test have higher (lower) power than Pedroni's (1999) test when a small- $T$ (high- $T$ ) are included in the panel. Gutierrez also shows that both these tests outperform Larsson et al.'s (2001) test. Based on this finding this study follows residual based cointegration tests suggested by Pedroni.

Pedroni's (1999, 2004) test is the extension of Engle and Granger's (1987) cointegration test for a single cross-section unit. The Engle and Granger cointegration test is based on the examination of the residual of a spurious regression performed using $I(1)$ variables. If the variables are cointegrated then the residual will be $I(0)$ and if the variables are not cointegrated then residual will be $I(1)$. Pedroni proposes tests for cointegration that allows for heterogeneous intercepts and trend across cross-section units. For two $I(1)$ variables $x$ and $y$ consider the following regression

$$
\begin{aligned}
& y_{i, t}=\alpha_{i}+\delta_{i} t+\beta_{1 i} x_{1 i, t}+\beta_{2 i} x_{2 i, t}+\ldots .+\beta_{M i} x_{M i, t}+e_{i, t} \\
& \text { for } t=1,2, \ldots . ., T ; i=1,2, \ldots \ldots, N ; m=1,2, \ldots \ldots ., M .
\end{aligned}
$$

The parameters $\alpha_{i}$ and $\delta_{\mathrm{i}}$ represent individual and trend effects respectively. Null hypothesis of the test is that $e_{i, t}$ is $I(1)$ against the alternative that $e_{i, t}$ is $I(0)$. To test whether the residuals are stationary following auxiliary regressions are estimated for each cross-section unit:

$$
\begin{aligned}
& e_{i, t}=\rho_{i} e_{i, t-1}+u_{i, t} \\
& e_{i, t}=\rho_{i} e_{i, t-1}+\sum_{j=1}^{p_{i}} \psi_{i, j} \Delta e_{i, t-j}+v_{i, t}
\end{aligned}
$$

Against the null hypothesis of no cointegration $\left(H_{0}: \rho_{i}=0\right)$, there are two alternative hypotheses, (1) the homogeneous alternative $\left[H_{1}:\left(\rho_{i}=\rho\right)<1\right.$, for all $\left.i\right]$, also called 
within-dimension test or panel statistic test and, (2) the heterogeneous alternative $\left(H_{1}: \rho_{i}<1\right.$, for all $\left.i\right)$, also called between-dimension or group statistic test. The panel cointegration test statistic $\aleph_{N, T}$ is constructed from the residuals from the either auxiliary regression mentioned above. Total eleven statistics are generated with varying degree of size and power for different $N$ and $T$. Pedroni shows that the standardized statistic is asymptotically normally distributed, $\frac{\aleph_{N, T}-\mu \sqrt{N}}{\sqrt{v}} \Rightarrow N(0,1)$, where $\mu$ and $v$ are Monte Carlo generated adjustment terms.

Data sources: A panel of 80 countries is used in this study ${ }^{2}$. While selecting the countries attention has been given so that countries from all stages of economic development are included in the sample. This is done to ensure that the phenomenon under study is not biased to any specific group of countries. Annual data series have been obtained from the Penn World Table (PWT)-2006 over the period 1951-2005. PWT calculates PPP exchange rate over GDP, that is, the PPP exchange rate is the national currency value of GDP divided by the real value of GDP in USA dollars. Data on population growth have been collected from World Development Indicator-2008.

\section{Analysis of empirical results}

This section reports and analyses panel unit root and cointegration test results. There are several panel unit root tests in the literature. However, there is no uniformly powerful test for the unit root hypothesis. This paper uses two most popular panel unit root tests, namely, MW and PP tests for testing unit roots in PPP exchange rates (PPP) and relative population growth rates (RPOPGR). MW test results based on both ADF and PP are presented in Table 2. In case of ADF, optimum lag length is chosen on the basis of Schwartz Information Criteria (SIC) and in case of PP Newey-West bandwidth is selected using Bartlett kernel.

Table 2: Panel Unit Root Test for all countries

\begin{tabular}{|c|c|c|c|c|}
\hline & \multicolumn{2}{|c|}{ Level } & \multicolumn{2}{|c|}{ First difference } \\
\hline Variables & Intercept & $\begin{array}{c}\text { Intercept \& } \\
\text { trend }\end{array}$ & Intercept & $\begin{array}{l}\text { Intercept \& } \\
\text { trend }\end{array}$ \\
\hline RPOPGR & $\begin{array}{c}91.423 \\
(0.180)\end{array}$ & $\begin{array}{c}80.923 \\
(0.450)\end{array}$ & $\begin{array}{c}371.961 * \\
(0.000)\end{array}$ & $\begin{array}{c}292.859 * \\
(0.000)\end{array}$ \\
\hline PPP & $\begin{array}{c}103.309 \\
(0.040)\end{array}$ & $\begin{array}{c}56.337 \\
(0.979)\end{array}$ & $\begin{array}{c}251.678^{*} \\
(0.000)\end{array}$ & $\begin{array}{c}201.452 * \\
(0.000)\end{array}$ \\
\hline
\end{tabular}

\footnotetext{
${ }^{2}$ Please see the Annex -A Table for the country list.
} 
Note: $*, * *, * * *$ indicate significant at $1 \%, 5 \%$ and $10 \%$ respectively. Figures without parenthesis are test statistics and those inside parentheses are respective probabilities, which are computed using an asymptotic Chi-square distribution.

Test results show that all series under consideration contain unit root at their level. However, their first difference are stationary, that is, the variables are I(1). When variables are integrated to order one, the next issue of interest in empirical research is to search for long run relationship between them. Therefore, the cointegration analysis proposed by Pedroni $(1999,2004)$ is used next and all eleven Pedroni's tests based on the null of no cointegration are considered. Also various sources of heterogeneity under the alternative also introduced in order to allow the cointegration relation to be countryspecific. The results are reported in Table 3.

Table 3: Panel Cointegration Test

Null Hypothesis: No cointegration

Alternative hypothesis: common AR coefficients (within-dimension)

\begin{tabular}{lcccc}
\hline & & \multicolumn{3}{c}{ Weighted } \\
& Statistic & Prob. & Statistic & Prob. \\
\hline Panel v-Statistic & -0.837303 & 0.2810 & -1.893460 & $0.0664 * * *$ \\
Panel rho-Statistic & -2.615808 & $0.0130^{*}$ & -2.641389 & $0.0122^{* *}$ \\
Panel PP-Statistic & -5.916220 & $0.0000^{*}$ & -6.995788 & $0.0000^{*}$ \\
Panel ADF-Statistic & -7.757581 & $0.0000^{*}$ & -8.889260 & $0.0000^{*}$ \\
\hline
\end{tabular}

Alternative hypothesis: individual AR coefficients (between-dimension)

\begin{tabular}{lcc}
\hline & Statistic & Prob. \\
\hline Group rho-Statistic & 1.356103 & 0.1591 \\
Group PP-Statistic & -3.469555 & $0.0010^{*}$ \\
Group ADF-Statistic & -8.189316 & $0.0000^{*}$ \\
\hline
\end{tabular}

Note: $* * *, * * *$ indicate significant at $1 \%, 5 \%$ and $10 \%$ respectively. Trend assumption: Deterministic intercept and trend. Lag selection: Automatic SIC with a max lag of 4.

Cointegration results are encouraging and show that the variables are cointegrated under both homogeneous and heterogeneous alternatives. Out of eleven test statistics, nine are highly significant indicating a long run equilibrium relationship between purchasing power parity exchange rate and relative population growth. This result suggests that there is a common stochastic trend among PPP exchange rate and relative population growth that makes it likely that these two variables move together in the selected countries.

Next the sample countries are divided into high income and low income economies in order to see whether the economic condition (stage of development) has any effect on 
the hypothesized relationship between PPP exchange rate and relative population growth. Countries are classified into high income and low income countries based on the World Bank classification as reported in World Development Indicator (WDI)2008. In WDI-2008 countries are divided into four groups: low income, middle income, upper middle income and high income. For the sake of simplicity countries in the sample that fall in low income and middle income group are included in low income economies and countries that fall in upper middle income and high income groups are included in high income economies. Table 4 reports unit root test results for high and low income countries respectively.

Table 4 Fisher unit root test for high and low income countries

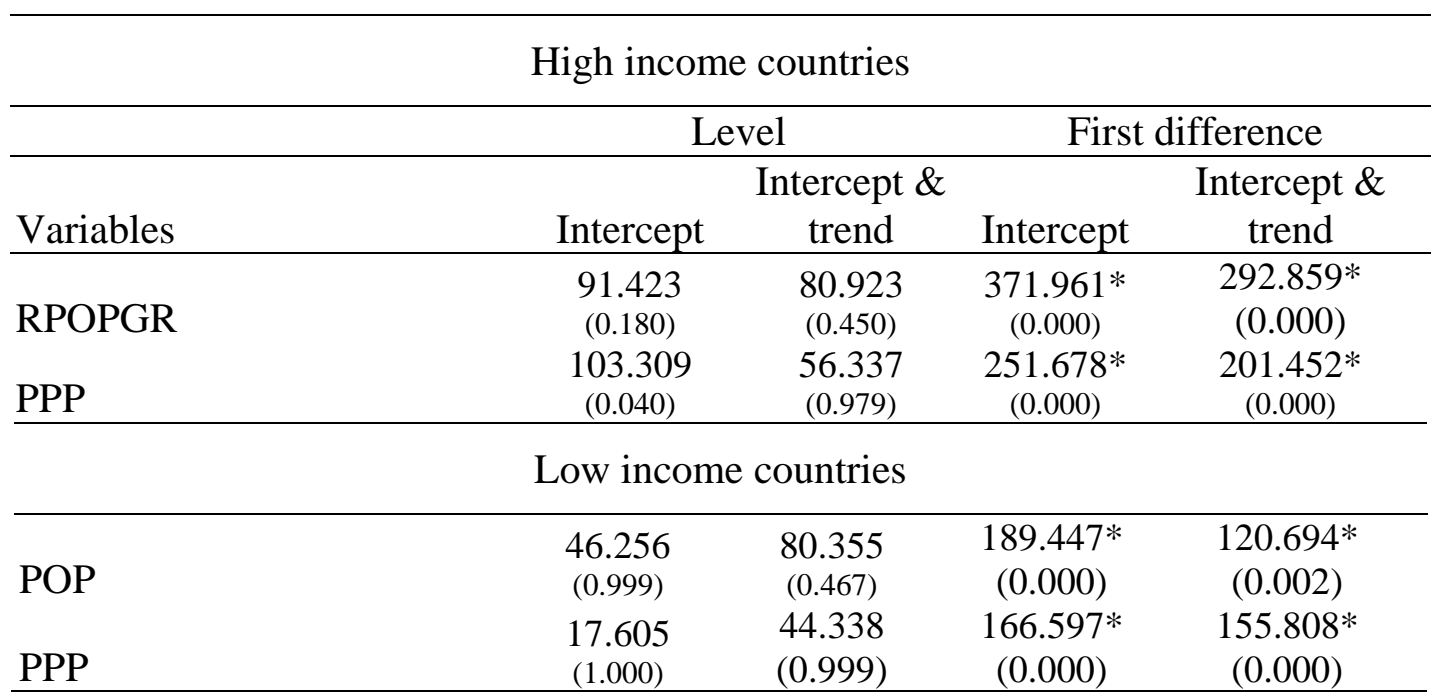

Note 1: $*, * *, * * *$ indicate significant at $1 \%, 5 \%$ and $10 \%$ respectively. Figures without parenthesis are test statistics and those inside parentheses are respective probabilities, which are computed using an asymptotic Chi-square distribution.

Table-5: Pedroni Residual Cointegration Test (High income countries)

Null Hypothesis: No cointegration

\begin{tabular}{lcccc}
\hline \multicolumn{5}{c}{ Alternative hypothesis: common AR coefs. (within-dimension) } \\
& Statistic & Prob. & Statistic & Prob. \\
\hline Panel v-Statistic & -0.837303 & 0.2810 & -1.893460 & $0.0664^{* * *}$ \\
Panel rho-Statistic & -2.615808 & $0.0130^{*}$ & -2.641389 & $0.0122^{* *}$ \\
Panel PP-Statistic & -5.916220 & $0.0000^{*}$ & -6.995788 & $0.0000^{*}$ \\
Panel ADF-Statistic & -7.757581 & $0.0000^{*}$ & -8.889260 & $0.0000^{*}$ \\
\hline \multicolumn{5}{c}{ Alternative hypothesis: individual AR coefs. (between-dimension) } \\
\hline \multicolumn{5}{c}{} \\
\hline Group rho-Statistic & Statistic & Prob. & \\
Group PP-Statistic & 1.356103 & 0.1591 & \\
Group ADF-Statistic & -3.469555 & $0.0010^{*}$ & \\
\hline
\end{tabular}


Note: $* * *, * * *$ indicate significant at $1 \%, 5 \%$ and $10 \%$ respectively. Trend assumption:

Deterministic intercept and trend. Lag selection: Automatic SIC with a max lag of 4.

Table 4 reveals that the unit-root null hypothesis cannot be rejected at the $5 \%$ level for the variables under consideration and for both groups of high income and low income countries. Next, those tests are also applied on the variables taken in first differences and the results find evidence in favor of the rejection of the non-stationary hypothesis for all series, which justifies the possibility of cointegration. Therefore, Pedroni's cointegration tests are used for both groups of countries and the results are reported in Tables 5 and 6.

Table-6: Pedroni Panel cointegration test (Low income countries)

Null Hypothesis: No cointegration

Alternative hypothesis: common AR coefs. (within-dimension)

\begin{tabular}{lcccc}
\hline & & \multicolumn{3}{c}{ Weighted } \\
& Statistic & Prob. & Statistic & Prob. \\
\hline Panel v-Statistic & 3.982307 & $0.0001^{*}$ & 0.636837 & 0.3257 \\
Panel rho-Statistic & -5.500899 & $0.0000^{*}$ & 2.409225 & $0.0219^{* *}$ \\
Panel PP-Statistic & -12.09419 & $0.0000^{*}$ & 2.123744 & $0.0418^{* *}$ \\
Panel ADF-Statistic & -19.48331 & $0.0000^{*}$ & -3.748827 & $0.0004^{*}$ \\
\hline
\end{tabular}

Alternative hypothesis: individual AR coefs. (between-dimension)

\begin{tabular}{lcc}
\hline & Statistic & Prob. \\
\hline Group rho-Statistic & 4.348786 & $0.0000^{*}$ \\
Group PP-Statistic & 3.548211 & $0.0007^{*}$ \\
Group ADF-Statistic & -3.873064 & $0.0002 *$ \\
\hline
\end{tabular}

Note: $* * *, * * *$ indicate significant at $1 \%, 5 \%$ and $10 \%$ respectively. Trend assumption: Deterministic intercept and trend. Lag selection: Automatic SIC with a max lag of 4.

Cointegration test results for high income countries reported in Table-5 show that nine, out of eleven, test statistics are significant at $1 \%, 5 \%$ or $10 \%$ levels, which implies that there is long run equilibrium relationship between PPP exchange rate and relative population growth. The results for low income countries reported in Table 6 show that ten out of eleven test statistics are significant at $1 \%$ or $5 \%$ levels. Recall that nine out of eleven statistics are statistically significant when cointegration tests involve all countries in the sample. Although there are clear differences between developed and developing countries in terms of macroeconomic stability, openness and private and public investment yet there is no significant changes in empirical findings when countries are splitted based on their income group. One possible explanation is that liberalization reform programs in developed and developing countries over the past 
years making both set of economies more competitive than ever before. The other explanation is that capital and labour inputs tend to move together with each other and with the scale of the economy making possible to obtain similar results for both developed and developing countries. In addition, wage occupies major part of production cost; any change in wage will affect price level. This is true both for developing and developed countries. In developing countries unemployment is high, which may give an impression that change in working age population will not affect wage and hence price level. However, skilled workforces in developing countries are still in limited sizes. So any change in working age population also brings changes in skilled workforce and hence wage and price.

However, as there is evidence of cross-sectional dependence it is instructive to consier this issue while examining long-run relationship between PPP exchange rate and relative population growth. To handle this problem we use panel cointegration test proposed by Westerlund (2007). This test handles the problem of cross-sectional dependence by bootstrapping the critical values of the test statistics. In this cointegration test, four test statistics are proposed; two are designed to test the alternative that the panel is cointegrated as a whole, while the other two are designed to test the alternative that variables in at least one cross-section unit are cointegrated. The former two statistics are referred to as group statistics $\left(G_{\tau}\right.$ and $\left.G_{\alpha}\right)$, while the later two are referred to as panel statistics $\left(P_{\tau}\right.$ and $P_{\alpha}$ ). The null hypothesis of this test is no error correction. If null is rejected then there is evidence of long-run or cointegrating relation between the variables in question. Table-7 reports the results of this cointegration test. Column (4) of the table reports p-value and column (5) reports bootstrapped p-values with 500 replications.

Table-7: Westerlund (2007) cointegration test

\begin{tabular}{ccccc}
\hline $\begin{array}{c}\text { Statistic } \\
(1)\end{array}$ & $\begin{array}{c}\text { Value } \\
(2)\end{array}$ & $\begin{array}{c}\text { Z-value } \\
(3)\end{array}$ & $\begin{array}{c}\text { P value } \\
(4)\end{array}$ & $\begin{array}{c}\text { Robust p values } \\
(5)\end{array}$ \\
\hline \multicolumn{5}{c}{ All countries } \\
\hline$G_{\tau}$ & -1.575 & 8.714 & 1.000 & 0.730 \\
$G_{\alpha}$ & -4.161 & 10.326 & 1.000 & 0.992 \\
$P_{\tau}$ & -6.593 & 14.064 & 1.000 & $0.076^{* * *}$ \\
$P_{\alpha}$ & -1.507 & 10.832 & 1.000 & 0.886 \\
\hline \multicolumn{5}{c}{ High income countries } \\
\hline \multicolumn{5}{c}{}
\end{tabular}




\begin{tabular}{ccccc}
\hline$G_{\tau}$ & -1.282 & 8.439 & 1.000 & $0.100^{* * *}$ \\
$G_{\alpha}$ & -0.477 & 10.728 & 1.000 & $0.034^{* *}$ \\
$P_{\tau}$ & 0.012 & 15.289 & 1.000 & 0.704 \\
$P_{\alpha}$ & 0.007 & 9.221 & 1.000 & 0.704 \\
\hline \multicolumn{5}{c}{ Low income countries } \\
\hline$G_{\tau}$ & -1.543 & 6.405 & 1.000 & 0.422 \\
$G_{\alpha}$ & -0.957 & 10.281 & 1.000 & 0.498 \\
$P_{\tau}$ & -5.743 & 8.710 & 1.000 & $0.016^{* *}$ \\
$P_{\alpha}$ & -0.406 & 8.795 & 1.000 & 0.416 \\
\hline
\end{tabular}

Note: *,**,*** indicate significant at $1 \%, 5 \%$ and $10 \%$ respectively.

Test results show that with bootstrapping we cannot reject the existence of cointegrating relationship between PPP exchange rate and relative population growth. When all countries are considered, null of no error correction is rejected at $10 \%$ significance level for one of the panel statistic. For high income countries null is rejected for the two group statistics (at 10\% and 5\% significance level). It indicates that PPP exchange rate and relative population growth are cointegrated in at least one cross-section unit. For low income countries null of no error correction is rejected at $5 \%$ significance level for one of the panel statistic. These results indicate that existence of cross-sectional dependence does not invalidate the results obtained in Pedroni's residual based cointegration test. It signifies the fact that the effect of relative population growth rate is not affected by any shock common to all countries.

Having found convincing evidence on the cointegrating relationship between PPP exchange rate and relative population growth, it is of practical interest to examine if the long-run coefficient is negative as hypothesized earlier. Fully Modified Ordinary Least Square (FMOLS) procedure proposed by Pedroni $(2000,2001)$ is used to test this hypothesized sign between these two variables. FMOLS is estimated both with and without common time dummies. Pedroni(2000) notes that common time dummies are intended to capture certain types of cross-sectional dependency. Table- 8 below reports the FMOLS results for the whole panel (individual country results reported in AnnexTable 2).

Table-8: Panel FMOLS estimation results

\begin{tabular}{lll}
\hline & Coefficients & $\mathrm{t}$ - statistics \\
\hline Without common time dummies & -31.007 & $-22.454^{* *}$ \\
With common time dummies & -3.989 & $-3.020^{* *}$ \\
\hline
\end{tabular}


Note: $* *$ indicate significant at $1 \%$ level.

The results show that in both the cases the long-run regression coefficient of the independent variable (relative population growth) is negative. This supports our argument that there is long-run negative relation between PPP exchange rate and relative population growth. It is worthwhile to note here that despite inclusion of time dummies, the long-run coefficient is still highly significant. This result is consistent with previous conclusion that even though there is cross-sectional dependencies, variables under consideration have long run equilibrium relation.

Time series results presented above turn out to be able to put in evidence a significant long-run relationship between PPP exchange rate and relative population growth. This relationship is largely accepted for most of the countries using the FMOLS (see Appendix Table 2). However, this result does not mean that BS hypothesis is uniformly supported by data for all countries, since 13 (Canada, Denmark, Ecuador, Finland, Germany, Hungary, Israel, Japan, Mauritius, New Zealand, Singapore, Sweden and United Kingdom) of them are proved not follow the BS path. The positive signs of long-run parameter estimates for these countries may be attributable to the failure of the BS hypothesis. The failure of the BS hypothesis may simply be that there are many additional long-run real exchange rate determinants that have to be considered. However, we leave that for our future research.

\section{Conclusion and policy implications}

This paper empirically examines the link between the relative population growth and PPP exchange rate through the so-called Balassa-Samuelson effect. It argues that relative population growth have significant role in explaining movement in national price levels through its impact on wages and that in turn affect PPP exchange rate. Since labor is immobile in the BS mechanism, so wage adjustment in response to increase (decrease) in working age population in the traded relative to non-traded good sector increase (decrease) the relative price of non-traded goods. This tends to appreciate (depreciate) real exchange rate. The finding of this paper is thus consistent with the BS hypothesis that operates through the wage rate. This paper relies on panel data and recent advances in panel unit-root and panel cointegration in testing the long run equilibrium relationship between relative population growth rates and PPP exchange rates for 80 countries and provides strong results supporting the hypothesis. This result is consistent with earlier finding obtained in Aloy and Gente (2005) and 
Andersson and Österholm (2005). These authors use different data sets and methodologies. However, our result is directly comparable with Salim and Hassan (2009) although their underlying conceptual framework for the empirical analysis is transaction demand for money which is ad hoc and untenable.

Our finding has various major implications in the International Economics in general and policy decisions in particular. Among others, the relative population growth rates have important role in explaining real exchange rate behavior. Relative population growth could invalidate the PPP hypothesis in the long run due to the BS effect. Since PPP is main edifice of most of the monetary exchange rate models, failure of PPP doctrine help collapse these models and thus, policy suggestions based on these models would then be inapplicable. Hence, the role of relative population growth has important implications in dealing with issues in International Economics such as exchange rate determination. 


\section{References}

Aloy, M. and Gente, K. 2005. How an aging population can explain the real appreciation of the Yen/US Dollar?; CEDERS Working Paper 2005.

Andersson, A. and Osterholm, P. 2005. Forecasting Real Exchange Rate Trends Using Age Structure Data- The Case of Sweden; Applied Economics Letter, 12: $267-272$.

Bahmani-Oskooee M. and Miteza, I. 2004. Panel cointegration and productivity bias hypothesis (in exchange rates); Journal of Economic Studies, 31: 448-456.

Bahmani-Oskooee, M. 1992. A Time-Series Approach to Test the Productivity Bias hypothesis in Purchasing Power Parity; Kyklos, 45:227-236.

Balassa, B. (1964), The Purchasing Power Parity Doctrine: A Reappraisal, Journal of Political Economy 72 (6): 584-596.

Baltagi, B. H., Bresson, G. and Pirotte, A. 2007. Panel Unit Root Test and Spatial Dependence; Journal of Econometrics, 22: 339-360.

Banerjee, A. 1999. Panel data unit root and cointegration: An overview; Oxford Bulletin of Economics and Statistics, 61:607-629.

Betts, C. and Devereux, M. B. 1996. The exchange rate in a model of pricing to market; European Economic Review, 40: 1007-1021.

De Gregorio, Jose, Alberto Giovanniniand Holger C. Wolf 1994. International evidence on tradables and nontradables inflation. European Economic review 38(6):1225-1244.

Dornbusch, R. 1987. Exchange rates and prices; American Economic Review, 77: 93-106.

Dornbusch, R. and Krugman, P. 1976. Flexible exchange rates in the short run; Brookings Papers on Economic Activity, 3: 537-575.

Drine, I. and Rault, C. 2003. Do panel data permit the rescue of the BalassaSamuelson hypothesis for Latin American countries?; Applied Economics, 35: 351-359.

Engle, R. F., and Granger, C.W. J. 1987. Co-integration and Error Correction: Representation, Estimation, and Testing; Econometrica, 55:251-276.

Frenkel, J. A. 1978. Purchasing Power Parity: doctrinal perspective and evidence from the 1920s; Journal of International Economics, 8:169-191.

Genius, M. and Tzouvelekas, V. 2008. The Balassa-Samuelson Productivity Bias Hypothesis: Further Evidence Using Panel Data; Agricultural Economics Review, 9: 41-55.

Gregorio, José De, Giovannini, A. and Wolf, H. C. 1994. International evidence on tradables and nontradables inflation; European Economic Review, 35:12251244.

Gutierrez, L. 2003. On the Power of Panel Cointegration Tests: A Monte Carlo comparison; Economics Letters, 80:105-111.

Harrod, R. F. (1933), International Economics, London: Cambridge University Press 
Im, K.S., Pesaran, M. H. and Shin, Y. 2003. Testing for unit roots in heterogeneous panels; Journal of Econometrics, 115: 53-74.

Johansen, S. 1991. Estimation and Hypothesis Testing of Cointegrating Vectors in Gaussian Vector Autoregressive Models; Econometrica, 59:1551-1580.

Johansen, S. 1995. Likelihood-based Inference in Cointegrated Vector Autoregressive Models; Oxford University Press, Oxford.

Johansen, S. and Juselius, K. 1990. Maximum Likelihood Estimation and Inference on Cointegration with Applications to the Demand for Money; Oxford Bulletin of Economics and Statistics, 52: 169-211.

Kalyoncu, H. and Kalyoncu, K. 2008. Purchasing power parity in OECD countries: Evidence from panel unit root; Economic Modelling, 25: 440-445.

Kao, C. 1999. Spurious Regression and Residual-Based Tests for Cointegration in Panel Data; Journal of Econometrics, 90:1-44.

Krugman, P. 1986. Pricing to market when the exchange rate change; NBER Working Papers, Vol. 1926.

Larsson, R., Lyhagen, J. and Löthgren, M. 2001. Likelihood Based Cointegration Tests in Heterogeneous Panels; Econometrics Journal, 4:109-142.

Levin, A., Lin, C. F. and Chu, J. 2002. Unit root test in panel data: asymptotic and finite sample properties; Journal of Econometrics, 108: 1-24.

Lothian, J. R. and Taylor, M. P. 2008. Real Exchange rates over the past two centuries: How important is the Harrod-Balassa-Samuelson effect?; Economic Journal, 118: 1719-1741.

Maddala, G. S. and Wu, S. 1999. A comparative study of unit root tests with panel data and a new simple test; Oxford Bulletin of Economics and Statistics, 61:631-652.

Maddala, G. S., and Kim, In-Moo. 1998. Unit roots, cointegration, and structural change, Cambridge University Press, London.

Mark, N. 1990. Real and nominal exchange rates in the long run: an empirical investigation; Journal of International Economics, 28:115-136.

Minford, P. 1983. Labour market equilibrium in an open economy; Oxford Economic Papers, 35: 207-244.

Obstfeld, M. and Rogoff, K. 1996. Foundations of International Macroeconomics, Cambridge, Mass: MIT Press.

Obstfeld, M. and Rogoff, K. 2000. The six major puzzles in international macroeconomics: is there a common cause; NBER Working Papers, Vol. 7777.

Pedroni, P. (2000). "Fully Modified OLS for Heterogeneous Cointegrated Panels," in Baltagi, B., C.D. Kao (Eds.), Advances in Econometrics, Nonstationary Panels, Panel Cointegration and Dynamic Panels, Elsevier Science, New York, 93-130.

Pedroni, P. (2001). "Purchasing Power Parity Tests in Cointegrated Panels," The Review of Economics and Statistics, Vol. 83, 727-731. 
Pedroni, P. 2004. Panel Cointegration: Asymptotic and Finite Sample Properties of Pooled Time Series Tests with an Application to the PPP Hypothesis; Econometric Theory, 20: 597-625.

Pedroni, P. 1999. Critical Values for Cointegration Tests in Heterogeneous Panels with Multiple Regressors; Oxford Bulletin of Economics and Statistics, 61: 653-670.

Pesaran, M. H. 2004. General diagnostic tests for cross section dependence in panels; CESifo Working Paper No. 1229; Cambridge University, United Kingdom.

Phillips, P. C. B. 1991. Optimal Inference in Co-integrated System; Econometrica, 59: 282-306.

Ricardo, D. (1817). The Principle of Political Economy and Taxation, London: Dent.

Salim, R. and Hassan, K. 2009. Does the relative population growth affect purchasing power parity?; Applied Economics Letters, 16: 103-107.

Samuelson, P. A. (1964), Theoretical Notes on Trade Problems, Review of Economics and Statistics 46 (2): 145-154.

Sarantis, N. C. 1981. Employment, labor supply and real wages in market disequilibrium; Journal of Macroeconomics, 3: 335-354.

Sarno, L. and Taylor, M. P. 2002. The Economics of Exchange Rates, Cambridge University Press, London.

Taylor, M. P. 1988. An empirical examination of long-run Purchasing Power Parity using cointegration technique; Applied Economics, 20:1369-1381.

Westerlund, Joakim 2007. Testing for error correction in panel data; Oxford Bulletin of Economics and Statistics, 69: 709 - 748.

Wu, Jyh-Lin and Chen, Pei-Fen 2008. A revisit on dissecting the PPP puzzle: Evidence from a nonlinear approach; Economic Modelling, 25: 684-695.

Wu, Yangru 1996. Are Real Exchange Rates Nonstationary? Evidence from a Panel-Data Test; Journal of Money, Credit and Banking, 28: 54-63. 
Annex-Table 1: Country List

\begin{tabular}{|c|c|}
\hline High income countries & Low income countries \\
\hline Australia & Algeria \\
\hline Austria & Bangladesh \\
\hline Bahamas & Burundi \\
\hline Barbados & Cambodia \\
\hline Belgium & Central African Republic \\
\hline Bermuda & China \\
\hline Botswana & Colombia \\
\hline Canada & Congo, Republic of \\
\hline Chile & Cote d'Ivoire \\
\hline Costa Rica & Cuba \\
\hline Denmark & Dominican Republic \\
\hline Equatorial Guinea & Ecuador \\
\hline Finland & Egypt \\
\hline France & Fiji \\
\hline Gabon & Gambia, The \\
\hline Germany & Guatemala \\
\hline Hong Kong & Honduras \\
\hline Hungary & India \\
\hline Iceland & Jamaica \\
\hline Israel & Jordan \\
\hline Japan & Kenya \\
\hline Korea, Republic of & Lesotho \\
\hline Luxembourg & Malawi \\
\hline Macao & Maldives \\
\hline Malaysia & Mongolia \\
\hline Malta & Namibia \\
\hline Mauritius & Nepal \\
\hline Mexico & Nigeria \\
\hline Morocco & Pakistan \\
\hline Netherlands & Papua New Guinea \\
\hline New Zealand & Philippines \\
\hline Portugal & Senegal \\
\hline Singapore & Solomon Islands \\
\hline South Africa & Sri Lanka \\
\hline Spain & Swaziland \\
\hline St. Lucia & Syria \\
\hline Sweden & Tanzania \\
\hline Switzerland & Thailand \\
\hline Trinidad \&Tobago & Tunisia \\
\hline United Kingdom & Vanuatu \\
\hline
\end{tabular}


Annex-Table 2: FMOLS Estimation Results for Individual Countries

\begin{tabular}{|c|c|c|c|c|c|c|c|c|c|}
\hline \multirow[t]{2}{*}{ Countries } & \multicolumn{4}{|c|}{ Without common time dummies } & \multirow[t]{2}{*}{ Countries } & \multicolumn{4}{|c|}{ With common time dummies } \\
\hline & Coeff & t-stat & Coeff & t-stat & & Coeff & t-stat & Coeff & t-stat \\
\hline Algeria & -8.752 & $-5.238 * *$ & 17.447 & $5.554 * *$ & Jordan & -0.023 & $-2.582 *$ & 10.999 & $2.188 *$ \\
\hline Australia & -0.154 & -1.626 & -81.804 & $-3.429 * *$ & Kenya & -6.604 & $-3.150 * *$ & 25.435 & $3.915^{* *}$ \\
\hline Austria & & & & & Korea, & & & & \\
\hline & -1.662 & $0-0.336$ & -29.207 & $-2.600 * *$ & Republic of & -390.010 & $-3.876^{* *}$ & 256.244 & 1.281 \\
\hline Bahamas & -0.090 & $-4.184 * *$ & 0.271 & 0.003 & Lesotho & -0.693 & $-3.312 * *$ & 16.367 & 0.877 \\
\hline Bangladesh & -3.531 & $-4.062 * *$ & 9.869 & 0.143 & Luxembourg & -15.119 & -1.227 & -32.721 & $-2.780 * *$ \\
\hline Barbados & -0.230 & $-3.822 * *$ & -68.772 & $-2.134 *$ & Macao & -0.421 & $-4.153 * *$ & 13.429 & $3.958 * *$ \\
\hline Belgium & -66.259 & $-1.850^{*}$ & -55.397 & $-3.380^{* *}$ & Malawi & -1.084 & -1.058 & 5.143 & 1.487 \\
\hline Bermuda & -0.126 & $-2.133 *$ & 4.221 & 0.219 & Malaysia & -0.083 & $-2.839 * *$ & 17.752 & 0.475 \\
\hline Botswana & -0.723 & $-8.812^{* *}$ & 35.278 & $10.008^{* * *}$ & Maldives & -1.406 & $-6.461 * *$ & 38.688 & $7.443 * *$ \\
\hline Burundi & -13.783 & -1.391 & 0.588 & 0.086 & Malta & -0.007 & $-2.464 *$ & -12.691 & $-2.764 * *$ \\
\hline Cambodia & -306.490 & $-5.824 * *$ & -393.069 & $-4.317 * *$ & Mauritius & 0.315 & 0.102 & -39.881 & $-4.882 * *$ \\
\hline Canada & 0.006 & 0.242 & -49.457 & $-2.243^{*}$ & Mexico & -4.616 & $-5.382 * *$ & 88.939 & $4.484 * *$ \\
\hline Central & & & & & & & & & \\
\hline African & & & & & & & & & \\
\hline Republic & -45.920 & $-3.70 * * *$ & -9.848 & -0.674 & Mongolia & -99.175 & $-2.581 *$ & -130.81 & $-1.983 *$ \\
\hline Chile & -256.115 & $-6.591 * *$ & 240.232 & $2.727 * *$ & Morocco & -0.519 & $-6.598 * *$ & 95.760 & 5.225 \\
\hline China & -1.218 & $-6.464 * *$ & 12.528 & 0.243 & Namibia & -0.550 & $-2.833 * *$ & 10.278 & 1.681 \\
\hline Colombia & -568.286 & $-3.257 * *$ & 155.529 & 1.574 & Nepal & -9.904 & $-3.702 * *$ & -85.876 & $-9.448 * *$ \\
\hline Congo, & & & & & & & & & \\
\hline Republic of & -105.730 & -1.061 & 476.517 & 1.642 & Netherlands & -0.883 & -0.553 & -46.637 & $-5.003 * *$ \\
\hline & -102.221 & $-3.061 * *$ & -60.906 & -0.564 & New Zealand & 0.112 & 0.810 & -33.298 & $-3.535^{* *}$ \\
\hline Cote & & & & & & & & & \\
\hline d'Ivoire & -11.179 & -1.571 & 3.492 & 0.504 & Nigeria & -25.527 & $-2.044 *$ & -3.006 & -0.210 \\
\hline Cuba & -0.124 & $-1.830^{*}$ & -31.059 & -1.327 & $\begin{array}{l}\text { Pakistan } \\
\text { Papua New }\end{array}$ & -4.365 & $-2.283 *$ & -21.162 & -0.614 \\
\hline $\begin{array}{l}\text { Denmark } \\
\text { Dominican }\end{array}$ & 0.408 & 0.872 & -32.128 & $-5.108 * *$ & Guinea & -0.166 & -1.758 & -84.866 & $-6.228 * *$ \\
\hline Republic & -6.867 & $-4.638 * *$ & -125.207 & $-2.217^{*}$ & Philippines & -6.510 & $-3.460 *$ & -50.247 & -1.157 \\
\hline Ecuador & 0.004 & 0.136 & 59.914 & $9.893^{* *}$ & Portugal & -87.985 & $-2.520 *$ & -62.039 & $-2.285^{*}$ \\
\hline Egypt & -0.631 & $-4.932 * *$ & 15.799 & 0.338 & Senegal & -28.739 & $-1.904 *$ & 9.711 & 0.620 \\
\hline Equatorial & & & & & & & & & \\
\hline Guinea & -19.636 & $-2.08 *$ & -14.238 & -1.697 & Singapore & 0.032 & $3.375^{* *}$ & -2.380 & -0.427 \\
\hline Fiji & & & & & Solomon & & & & \\
\hline & -0.039 & -1.743 & 2.344 & 0.211 & Islands & -0.662 & $-2.69 * *$ & 17.614 & 0.690 \\
\hline Finland & & & & & & & & & \\
\hline & 8.684 & 1.809 & -53.764 & $-3.276^{* *}$ & South Africa & -1.376 & $-4.063 * *$ & 11.353 & 0.503 \\
\hline France & -2.346 & -0.601 & -55.134 & $-5.292^{* *}$ & Spain & -79.563 & $-5.203 * *$ & -78.639 & $-4.802 * *$ \\
\hline Gabon & -31.232 & -1.614 & -34.338 & -0.903 & Sri Lanka & -3.250 & $-2.260 *$ & 3.866 & 0.595 \\
\hline Gambia, & & & & & & & & & \\
\hline The & -1.204 & -1.443 & -17.376 & -0.629 & St. Lucia & -0.596 & $-3.325 * *$ & -47.129 & $-2.458 *$ \\
\hline Germany & 0.181 & 0.351 & -23.489 & $-2.261 *$ & Swaziland & -0.611 & $-4.815 * *$ & 29.883 & 1.299 \\
\hline Guatemala & -1.805 & $-2.016^{*}$ & -48.138 & $-2.743^{* *}$ & Sweden & 1.563 & 0.795 & -28.360 & $-2.406^{*}$ \\
\hline Honduras & -2.769 & $-3.323 * *$ & 57.812 & 5.322 & Switzerland & -0.068 & -0.539 & -28.787 & $-2.312 *$ \\
\hline Hong Kong & -0.321 & -0.528 & -5.467 & -0.646 & $\begin{array}{l}\text { Syria } \\
\text { Tanzania }\end{array}$ & -10.324 & $-5.404 * *$ & 10.585 & 1.383 \\
\hline Hungary & 51.937 & 0.489 & 35.778 & 2.593 & & -186.352 & $-5.216 * *$ & -359.41 & $-2.585^{*}$ \\
\hline Iceland & -68.214 & $-2.44 *$ & 28.683 & 1.718 & $\begin{array}{l}\text { Thailand } \\
\text { Trinidad }\end{array}$ & -2.749 & $-3.418 * *$ & 8.528 & 0.138 \\
\hline India & -4.038 & $-4.525 * *$ & -22.158 & -0.214 & \&Tobago & -0.875 & $-3.662 * *$ & 24.264 & 1.193 \\
\hline Israel & 0.5800 & 0.638 & -14.781 & $-2.024 *$ & Tunisia & -0.079 & $-7.879 * *$ & 37.682 & $4.563 *$ \\
\hline Jamaica & -15.972 & $-2.037^{*}$ & -4.052 & -0.534 & UK & 0.032 & 0.500 & -35.873 & $-4.169 * *$ \\
\hline Japan & 81.118 & $5.450 * * *$ & -181.706 & $-4.541 * *$ & Vanuatu & -7.116 & $-2.416^{*}$ & -20.459 & -0.987 \\
\hline
\end{tabular}

Note: $*$ and $* *$ indicate significant at $10 \%$ and $1 \%$ level. 